\title{
POLYMORPHISM OF RED BLOOD CELL IN PERIPHERAL BLOOD SMEAR OF THALASSEMIA AFFECTED PERSON.
}

\author{
H. P. Sapkal \\ Shri Shivaji College, Akola, M.S., India. \\ Corresponding author Email : hsapkal@rediffmail.com
}

\begin{abstract}
:
The thalassemias are classified according to which chain of the hemoglobin molecule is affected. In a thalassemias, production of the á globin chain is affected, while in â thalassemia production of the a globin chain is affected. Thalassemia produces a deficiency of a or $\beta$ globin, unlike sickle-cell disease which produces a specific mutant form of $\beta$ globin. $\beta$ globin chains are encoded by a single gene on chromosome 11; a globin chains are encoded by two closely linked genes on chromosome 16. Thus in a normal person with two copies of each chromosome, there are two loci encoding the $\beta$ chain, and four loci encoding the a chain thus it affected the morphology of red blood cell i.e. erythrocytes.
\end{abstract}

\section{Keywords:}

Thalassemia, RBC, haemoglobin.

\section{Introduction:}

Thalassemia (from Greek thalassa, sea, haima, blood; British spelling, -thalassaemiall) is an inherited autosomal recessive blood disease. In thalassemia, the genetic defect results in reduced rate of synthesis of one of the globin chains that make up hemoglobin. Reduced synthesis of one of the globin chains can cause the formation of abnormal hemoglobin molecules, and this in turn causes the anemia which is the characteristic presenting symptom of the thalassemias. The disease is particularly prevalent among Mediterranean peoples, and this geographical association was responsible for its naming:

Thalassa is Greek for the sea, Haema is Greek for blood. In Europe, the highest concentrations of the disease are found in Greece, including the Greek islands; in parts of Italy, in particular, Southern Italy and the lower Po valley; and in the Italian islands. Sicily, Sardinia (islands located at the Italian peninsula), 
Malta, Corsica (French island) and Cyprus and Crete (Greek islands) are heavily affected in particular. Other Mediterranean people, as well as those in the vicinity of the Mediterranean, also have high rates of thalassemia, including Middle Easterners, North Africans, and South Asians. The highest concentration of carriers (18\% of the population) is in the Maldives. The aim of the study was to assess different morphology of erythrocytes and other parameters like electrophoretic pattern from the patients with Thalassemia in some parts of Akola region, Maharashtra state, India. In Present study also aim to find out the carrier for thalassemia for to decrease the genetic load on population by avoiding consanguneous marrages.

\section{Material and Method:}

Major hospitals in Akola include the Civil Hospital, Chaudhary Hospital and Akola Critical Care Unit. From October 2009 to March 2010 a survey of patients with thalassemia major was conducted in Akola City. Thirty one thalassemic children were enrolled as study subjects who are Transfusion dependant from diffrent hospitals as well as blood bank. Specimen: A fresh venous sample collected in EDTA was used to prepare PBS. Peripheral blood smear was prepared for observed the polymorphism in blood cell.

\section{Result and Discussion:}

There are more data to support the protective advantage of $\mathrm{HbS}$ than for any other polymorphism. Nevertheless, although heterozygotes (HbAS) have consistently been shown to enjoy $>90 \%$ protection against severe and lethal malaria, they are not protected from symptomless parasitaemia, and the mechanism of protection remains controversial. To some extent, it almost certainly relates to the premature removal of iRBCs through an innate mechanism resembling that seen in G6PD deficiency. However, recent evidence from one population shows that HbAS protection increases with age. There was deformity in rbc cytoskeleton due to the oxygen deficiency. 


\section{Conclusion:}

This short review provides a flavour of some fascinating recent developments that relate to the polymorphisms of RBCs. It can been seen that thalassemia has had a profound effect on the genetic makeup of many tropical populations, and that studies that aim to understand how such polymorphisms affect malaria risk continue to provide important clues regarding the host- parasite relationship. The challenge for the future will be to convert these lessons into practical advances in the prevention and treatment of the disease.

\section{Acknowledgement:}

Author is thankful of University Grant Commission New Delhi, for financial support.

\section{Reference:}

Balgir RS, Mishra RK, Murmu B. (2003):- Clinical and hematological profile of hemoglobinopathies in two tribal communities of Sundargarh district in Orissa, India. Int. J. Hum. Genet. 3940: 209.

Balgir RS. (1996):-Genetic epidemiology of the three predominant abnormal hemoglobins in India. J Assoc Plys India ; 44: 25-28.

Dacie JV. Lewis S.(1994):- Practical Hematology, 8th edn. London, Churchill Livingston ; pp 258-260.

Gupta RB, Tiwary RS, Pande PL, Kutlar F, Oner C, Oner R, Huisman TH.(1991):- Hemoglobinopathies among the Gond tribal groups of central India; interaction of alpha- and beta-thalassemia with beta chain variants. Hemoglobin. 15: 441-458.

Piplani S. (2000) :-Hemoglobin E disorders in the north east India. J. Assoc.

Physicians India. 48: 1082-1084. Thein SL. (2005) :-Genetic modifiers of thalasemia. Hematologica. 90: 649-660.

Saxena A., Shubha P. (2002):- Thalassemia control by carrier screening: The Indian Scenario. Curr. Sc. 83: 291-295. Sarnaik SA. (2005):- Thalassemia and related haemoglobinopathies. Symposium. 72: 319-324.

Vives Corrons JL, Miquel-Garcia A, Pujades MA. (1995):- Increased susceptibility of microcytic red blood cells to in vitro oxidative stress. Eur J Hematol ; 55: 327-331 


\section{Observation :}
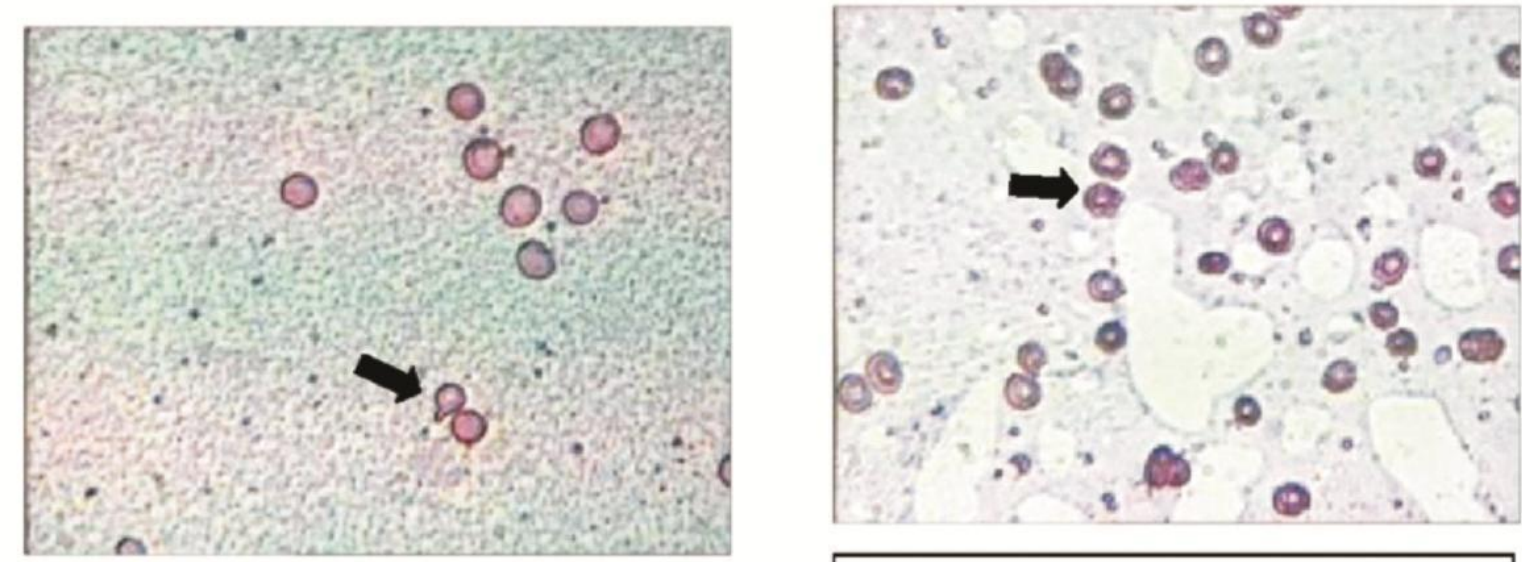

Fig 1:- Showing Tear drop cell

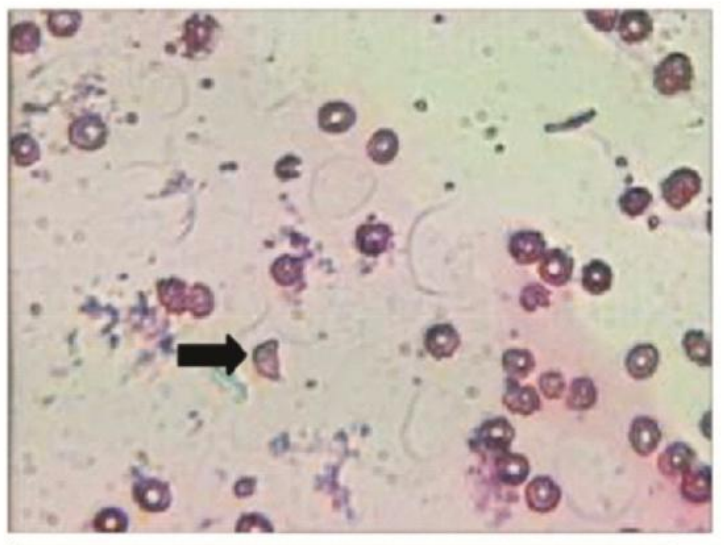

Fig 3:- Showing Schistocytes

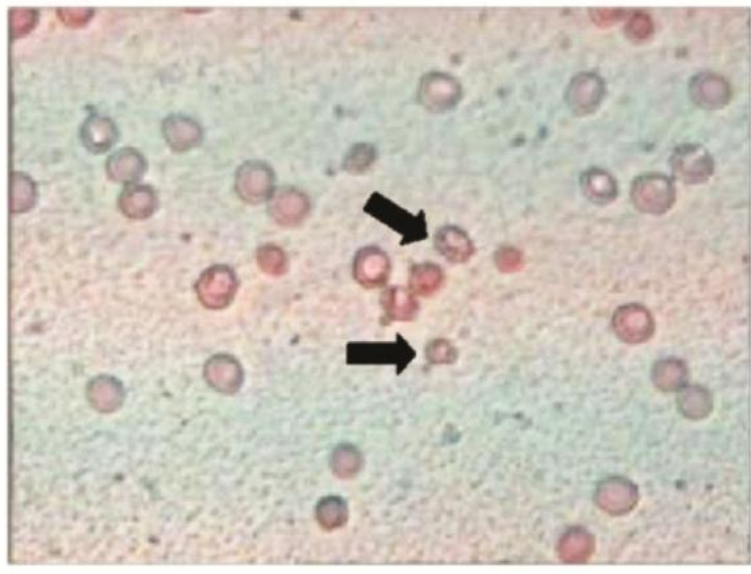

Fig 5:- Showing echinocytes and microcytes

Fig 2:- Showing Anisocytes cell

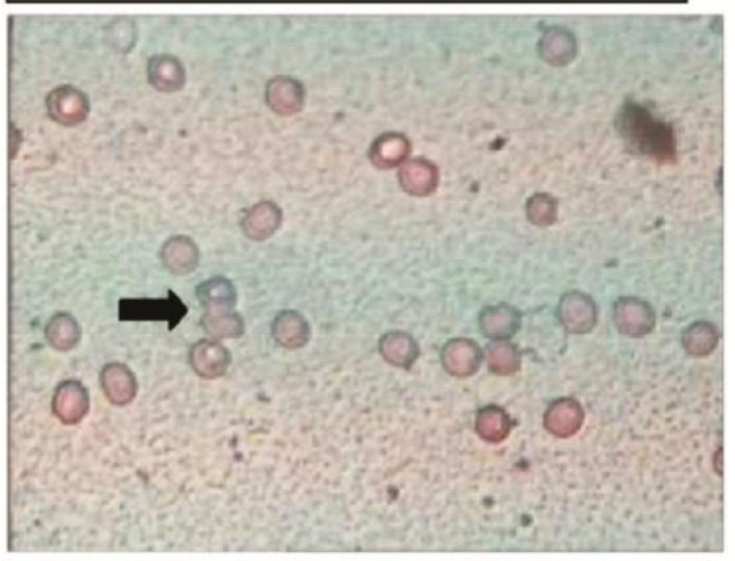

Fig 4:- Showing elliptocytes

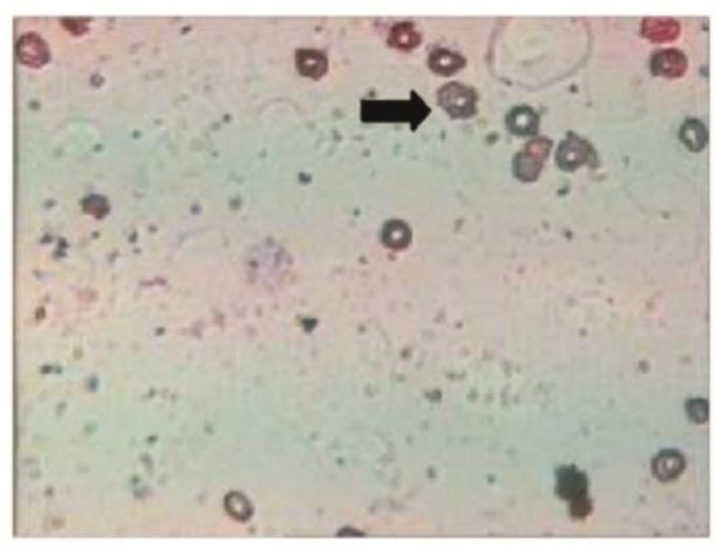

Fig 6:- Showing Acanthocytes 